\title{
Information System Design for Water Maintenance Activities at PT. Rezeki Surya Intimakmur
}

\author{
Fahmizal Derisfy, ${ }^{1,}$ Lusiana Gebrina², Syerlie Annisa ${ }^{3}$
}

1,2,3AMIK Mitra Gama, Duri, Indonesia

\begin{tabular}{l} 
Article Information \\
\hline Article History: \\
Accepted by the Editor: May 25, 2021 \\
Final Revision: June 28, 2021 \\
Published Online: June 30, 2021 \\
Keywords \\
\hline Application \\
Timesheet \\
Visual basic \\
Database \\
MySQL \\
Correspondence
\end{tabular}

E-mail: fahmizalderisfy@gmail.com*

\begin{abstract}
A B S T R A C T
PT. Rezeki Surya Intimakmur is a company engaged in home and building maintenance. Currently PT. Rezeki Surya Intimakmur is currently under a work contract with PT. Chevron Pacific Indonesia (PT. CPI) in terms of clean water maintenance activities in the company environment and the housing for employees of PT. CPI. In managing clean water maintenance data every day, the company uses a manual method by recording, which is filling out a work assignment form. This method results in the management of clean water maintenance work being hampered because data on workers and work results are often inconsistent with the actual situationapplications designed using research and product development methods with the waterfall model. The application design process uses Visual Basic.Net programming language and MySQL database. The resulting can make it easier for admin staff to manage clean water maintenance activities to produce maintenance reports.
\end{abstract}

This is an open access article under the CC-BY-SA license (c) (i) (2)

\section{Introduction}

PT. Rezeki Surya Intimakmur is a company engaged in home and building maintenance. Currently PT. Rezeki Surya Intimakmur is currently under a work contract with PT. Chevron Pacific Indonesia (PT. CPI) in terms of clean water maintenance activities in the company environment and the housing for employees of PT. CPI. In managing clean water maintenance data every day, the company uses a manual method by recording, which is filling out a work assignment form. It causes unstructured data entry, admin staff difficulties in sorting work assignment dates, less effective and efficient data storage or retrieval processes and the amount of time required in preparing maintenance reports. The objectives of the research are as follows: (1) Creating a computerized and integrated clean water maintenance information system; (2) Designing information systems to facilitate data management, facilitate access to storage and search for accurate data.

The information system combines information technology and user activities to carry out operations and management. In a broader sense, information systems lead to interactions between people, process algorithms, data, and technology development [1]. Water Treatment Plant or water treatment installation system is a clean water treatment system building. The notion of WTP can be interpreted as a useful system for managing clean water, starting from low-quality raw water and then processing it into water that can be 
properly consumed by the community [2]. Microsoft Visual Studio is an integrated development environment designed by Microsoft Corporation. Database support is needed to build an application with good storage and management. This study used MySQL database. MySQL is an application or SQL software [3]. MySQL is an RDBMS application (or database software) to manage databases more quickly, can store large amounts of data, and can be accessed by many interested parties and can execute process commands synchronously or simultaneously ( multi-threaded ) [4].

\section{Method}

This research was conducted at PT. Sustenance Surya Intimakmur is engaged in maintaining clean water in the PT. Chevron Pacific Indonesia. This type of research is research and development, namely research to build new products or improve or improve previous products [5]. The research model used is the waterfall research model, namely requirements definition, system and software design, implementation and unit testing, integration and system testing, operation and maintenance. There are two types of research and development, namely focusing on product design and evaluation, and the second type examining product development that has been carried out previously [6]. This model was chosen because it has a structured and systematic procedure according to the research issue [7]. This type of research has been widely used in various fields and has been successfully implemented, such as education, health, industry, and other fields [8].

\section{Results and Discussion}

\subsection{Requirements Definition}

The activities carried out at this stage are: (1) Studying the clean water maintenance management system in the PT. Chevron Pacific Indonesia which has been running; (2) Identify problems of clean water maintenance management activities that arise. Obstacles were found in manual file management and data management of cleaning staff who were not well organized; and (3) Determine user requirements for the new system. Based on the interviews and observations, functional requirements were obtained, namely the login page, main menu page, employee form, customer form, project form, job form, and work report page.

\subsection{System and Software Design}

The information system is designed with a structure. Starting with the design of context diagrams and data flow diagrams, and continued with entity relationship diagrams to determine the relationship between parties involved in the application. Furthermore, the design of the information system interface is carried out.

\subsubsection{Context Diagram}

Context diagram is a diagram that describes the process and limitations of a system. Context diagram is the top level of the data flow diagram that describes all inputs to the system or outputs from the system. Context diagrams provide an overview of the system as a whole. The system has a boundary [9]. The context diagram of the information system for data processing daily activities of clean water maintenance can be seen in Figure 1. 


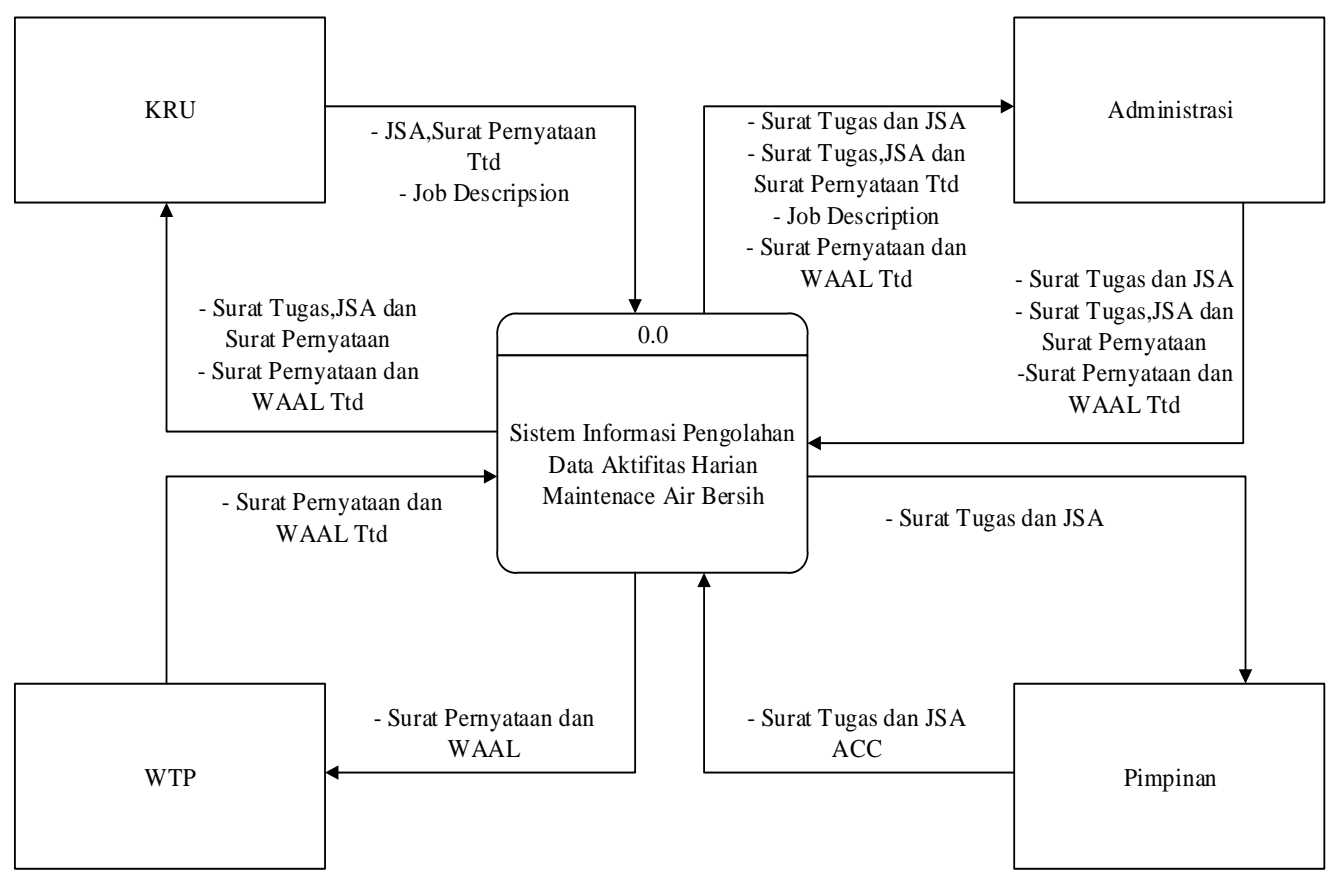

Figure 1. Context Diagram of Clean Water Maintenance Information System

\subsubsection{Data Flow Diagram}

The data flow diagram is a logical model that describes the source of data and the destination of the data that comes out of the system, the data stored, the processes carried out and the interaction between the stored data and the processes given to the data [10]. The data flow diagram that shows the details of the work flow and documents on this information system can be seen in Figure 2. 


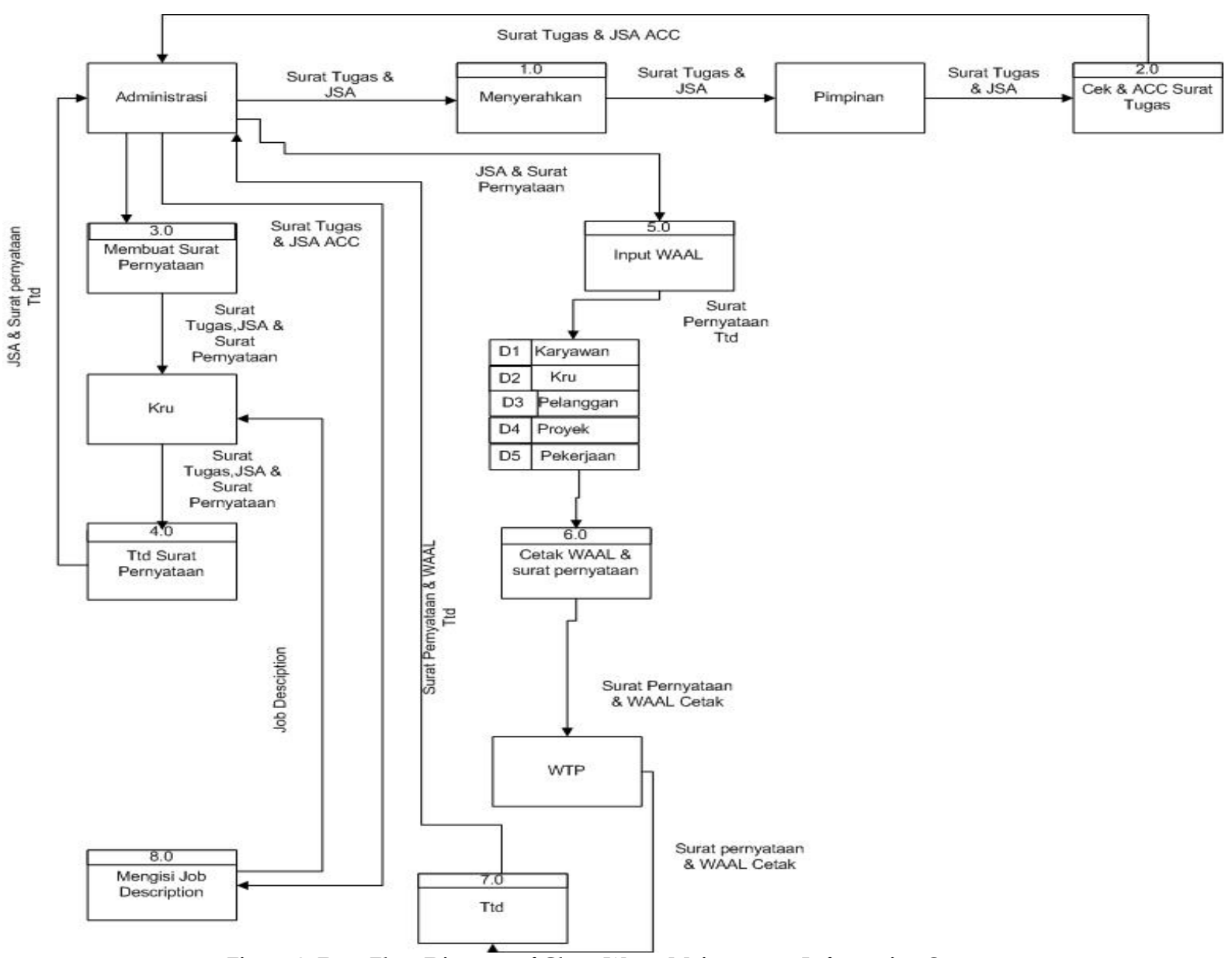

Figure 2. Data Flow Diagram of Clean Water Maintenance Information System

\subsubsection{Entity Relation Diagram}

The ERD relationship diagram contains entities and a collection of relationships, each of which has been paired with attributes that describe all identified events so that relationships between existing entities can be known. In addition, it presents the relationship in data processing [11]. The relationship diagram between entities that shows the details of the work flow and documents in this information system can be seen in Figure 3. 


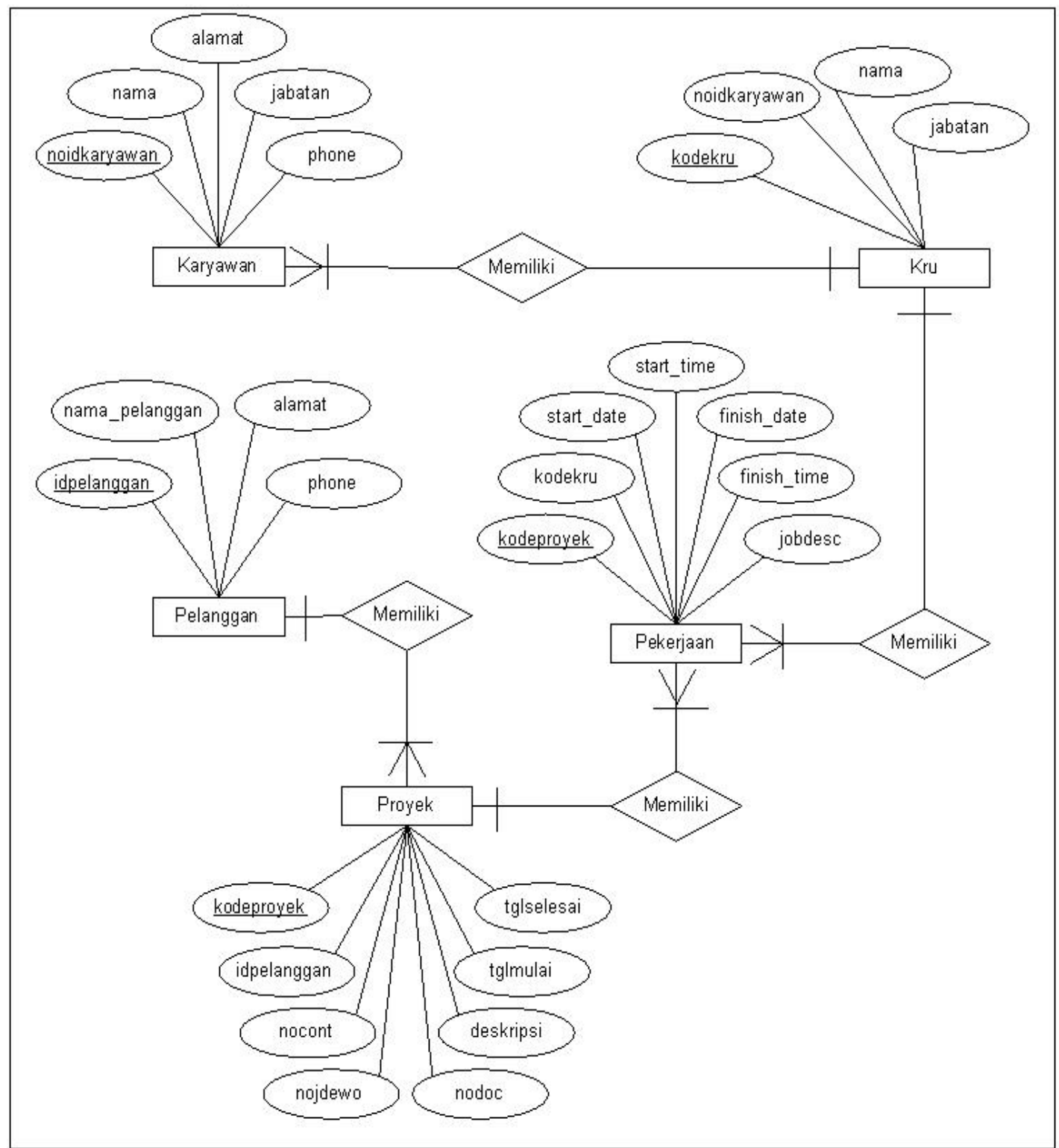

Figure 3. Diagram of Relationships Between Entities of Clean Water Maintenance Information System

\subsubsection{User Interface}

The login page view appears the first time the application is opened. The login form is intended to maintain system security from parties who are not entitled to access the system. The login page can only be accessed by administration and company leaders. Display form is presented in Figure 4.

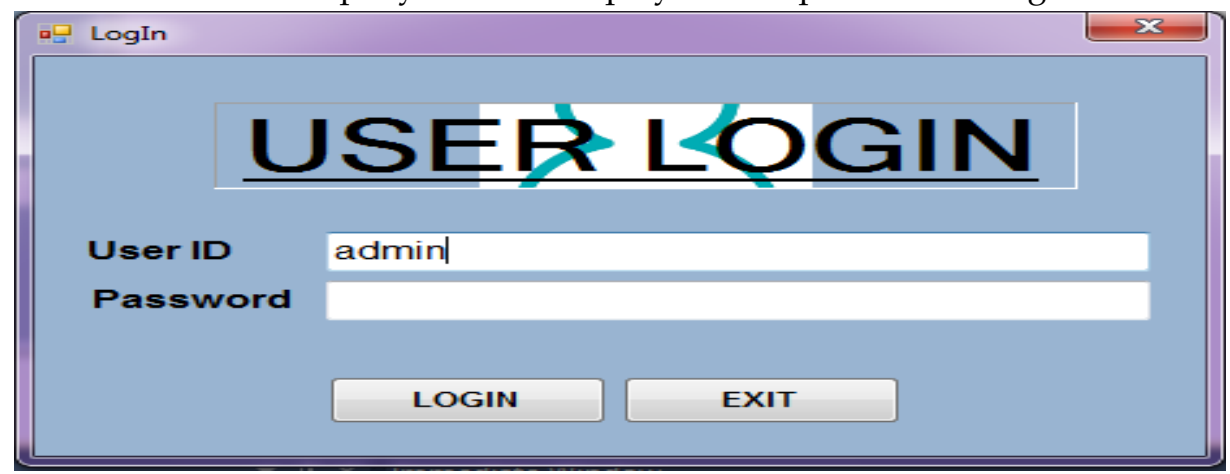

Figure 4. Login Page Display 
The main menu display will appear after the user (admin) has successfully logged into the information system. In this form the user can select the data management menu to be carried out according to the needs of the work, namely employee data, customers, job lists and clean water maintenance work reports. Display form can be seen in Figure 5.

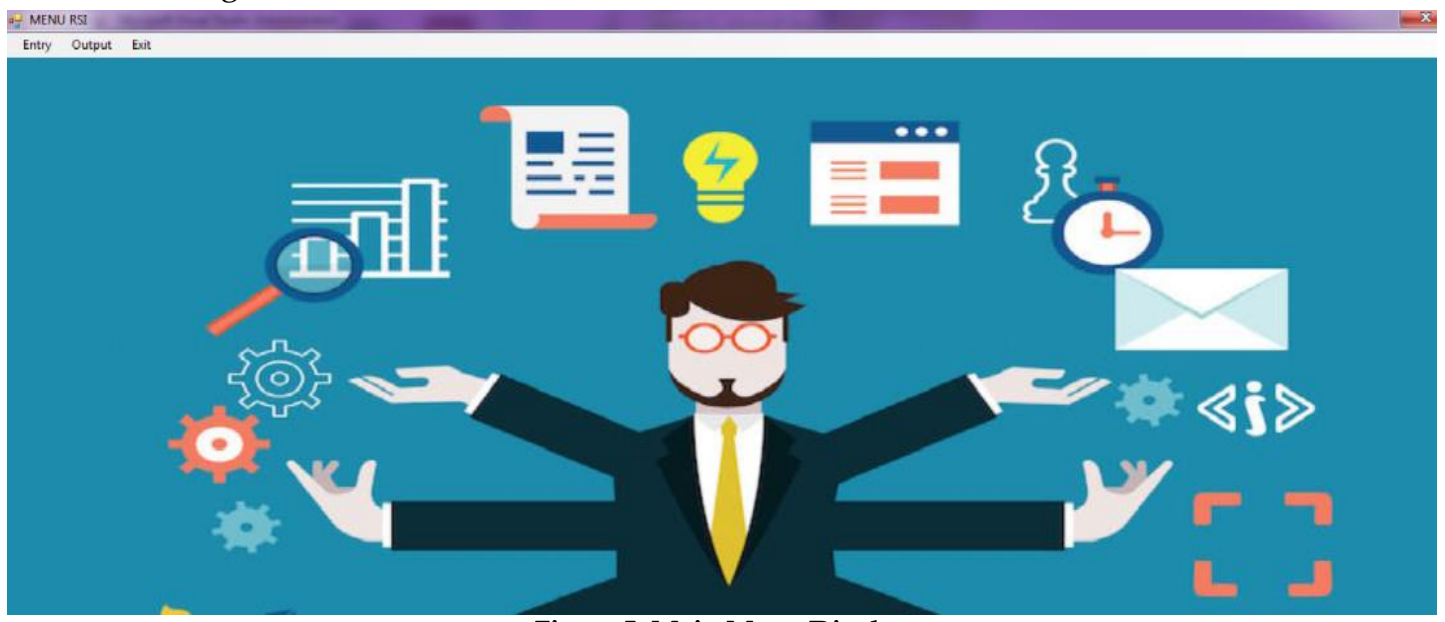

Figure 5. Main Menu Display

Employee form is a page that is used to manage employee data. In this form the administration can add, delete, and change data regarding employees who are responsible for clean water maintenance activities. Display form can be seen in Figure 6.

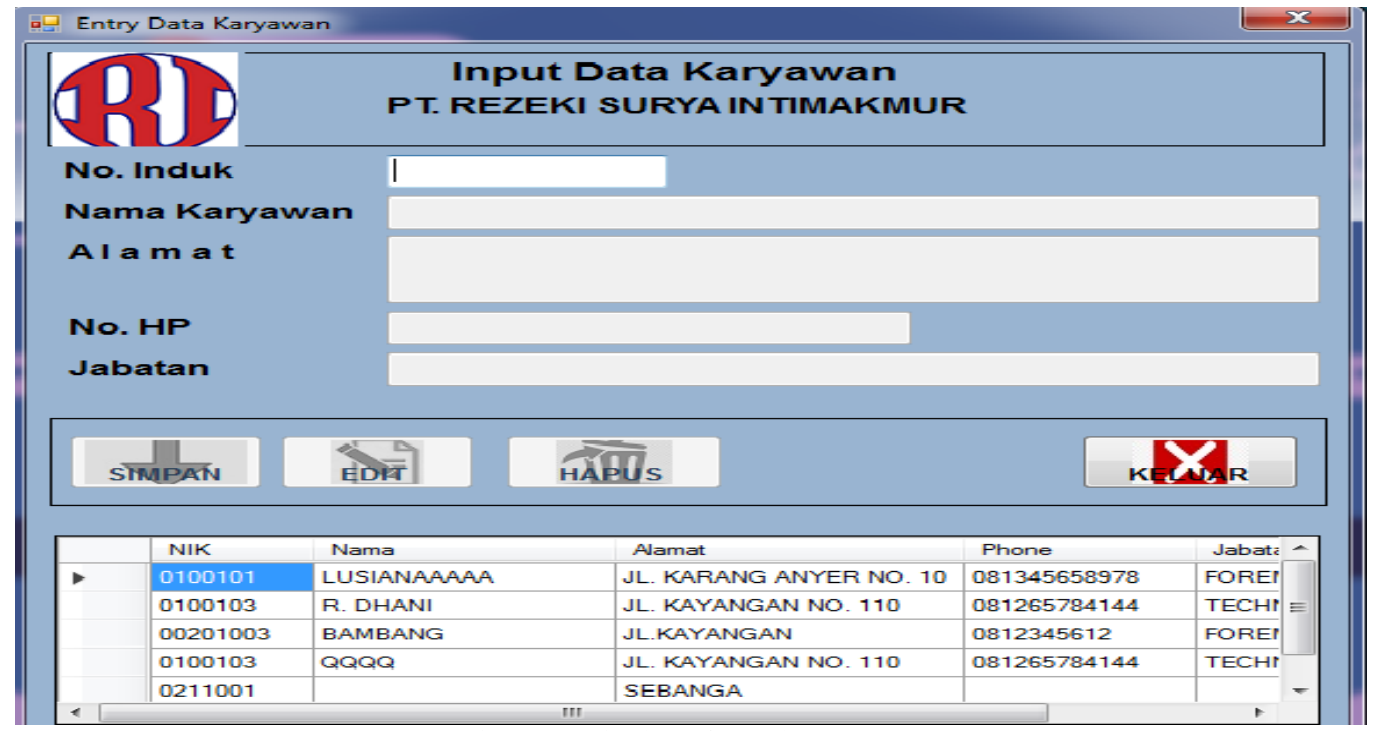

Figure 6. Display of Employee Form

Customer form is a page that is used to manage customer data other than PT. CPI. In this form the administration can add, delete, and change data regarding customers in clean water maintenance activities. The display form can be seen in Figure 7. 


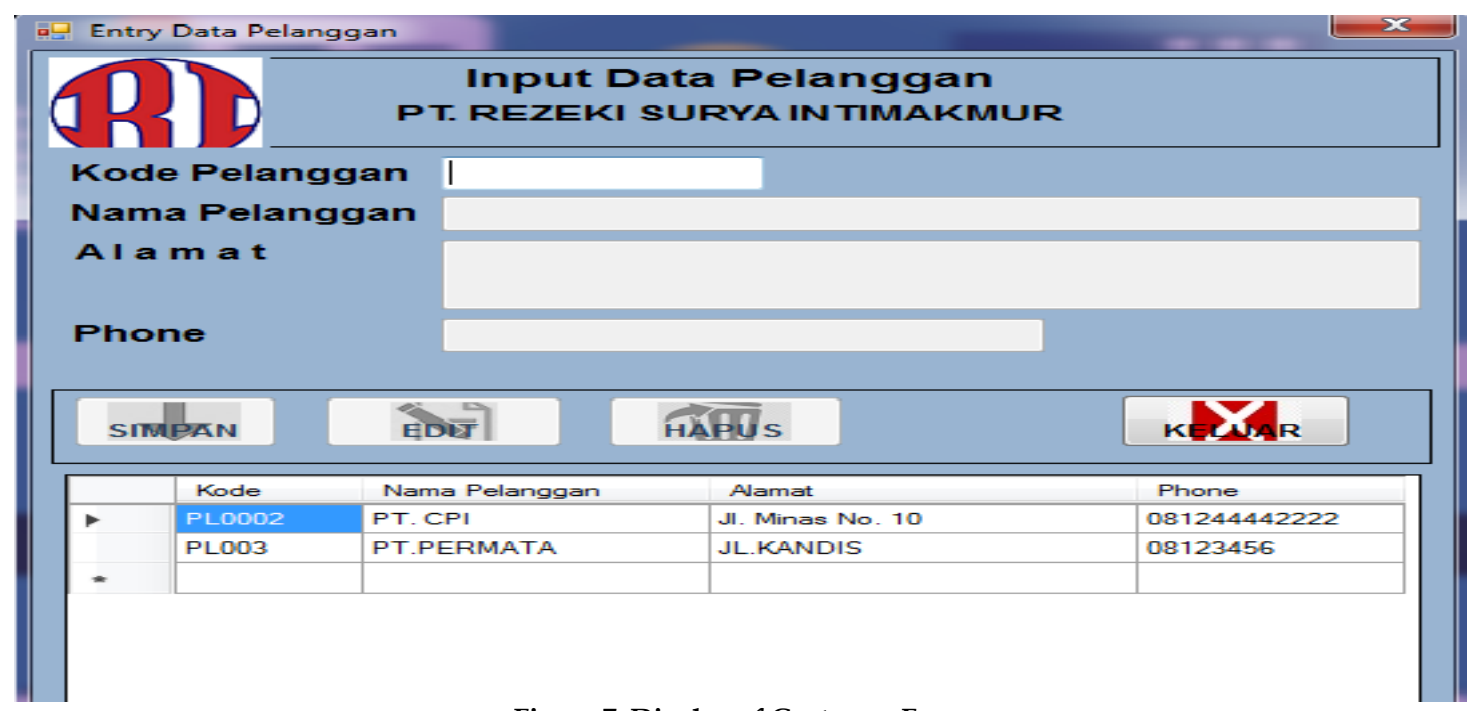

Figure 7. Display of Customer Form

The job form is a page that is used to manage detailed data on clean water maintenance work. In this form the administration can add, delete, and change data regarding the data of the work performed. Display form can be seen in Figure 8 .

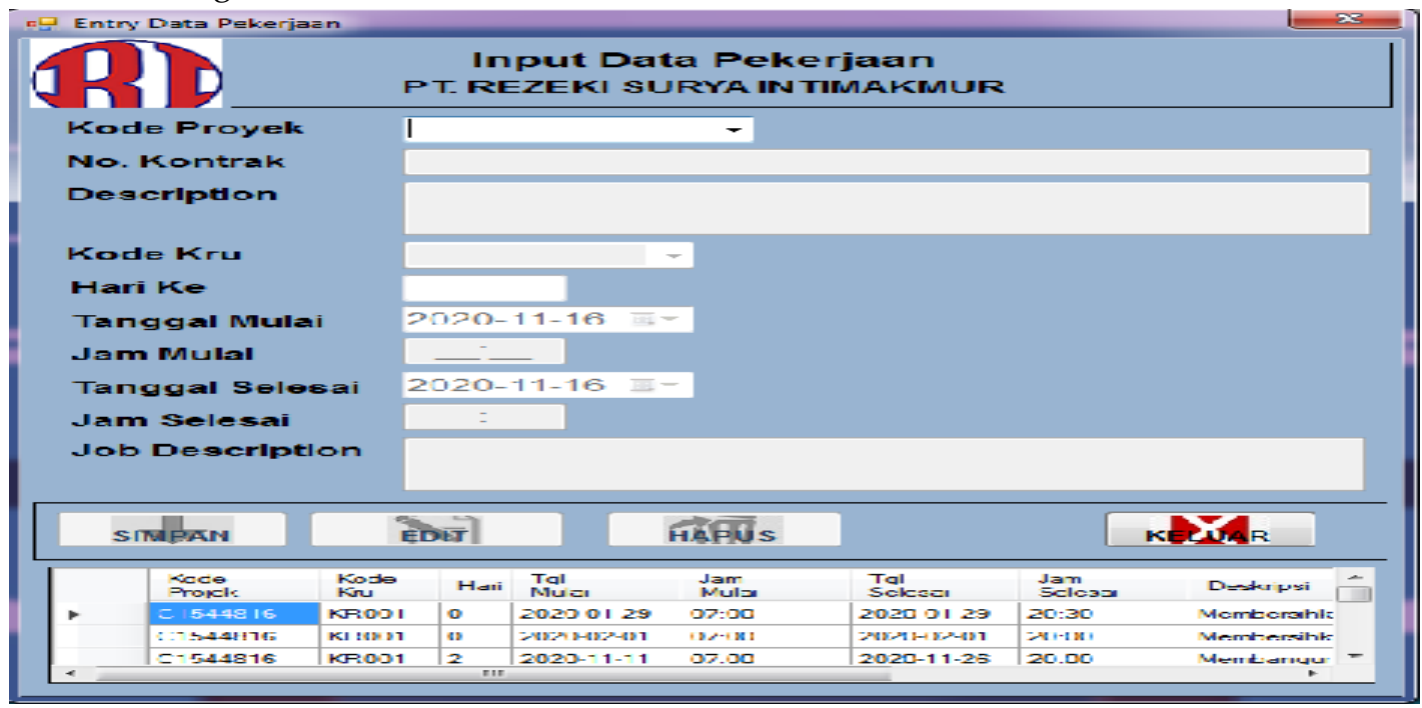

Figure 8. Display of Job Form

The project form is a page that is used to manage project detail data obtained by the company. In this form the administration can add, delete, and change data regarding the data of the work performed. Display form can be seen in Figure 9. 


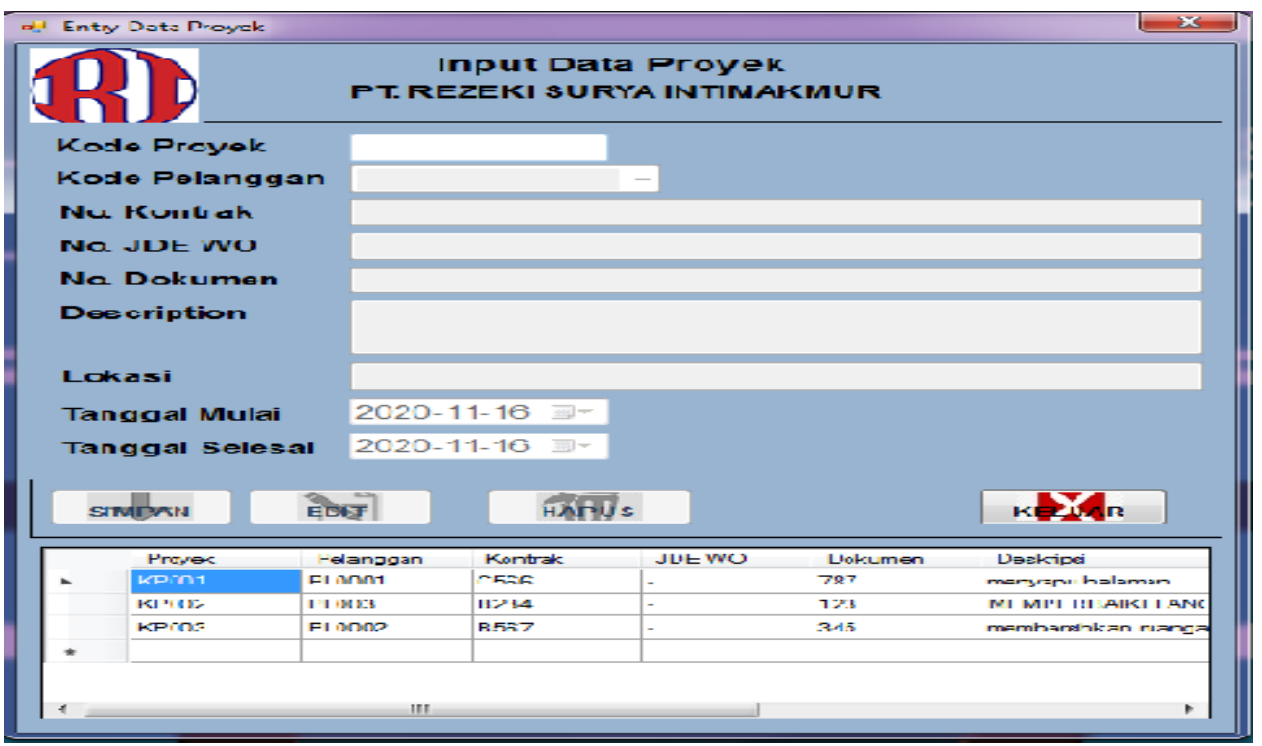

Figure 9. Project Form Display

The work report will display information regarding the details of clean water maintenance activities at PT. Surya Intimakmur's sustenance. Job reports can be searched by NIL, employee name, customer, project, or job. This report can be displayed and printed if the administration has added all the data. The form of the report can be seen in Figure 10 and Figure 11.

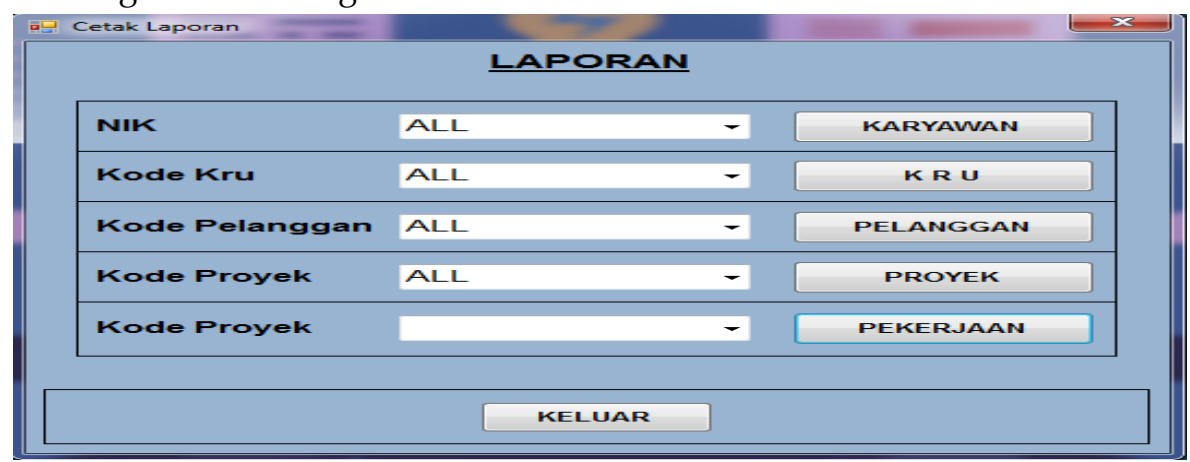

Figure 10. Job Result Report Search Page

\begin{tabular}{|cc|}
\hline & PT. REZEKI SURYA INTIMAKMUR \\
IIn.Fatmawati Raya No.33C \\
No.Telp 021 7504141
\end{tabular}

\section{LAPOKAN PEKERJALN}

Kode Provek : KP003

Kontrak :

Pekerioan

Kodc Kru : KROV2

\begin{tabular}{|c|c|c|c|c|c|}
\hline Dav & Staı I Date & Start Time & Finishı Date & Fiıislı Tiıne & Jub Desta iutiun \\
\hline 1 & $2020-11-08$ & - & $20 \div 0-11-0.8$ & - & \\
\hline 1 & $20>0-11-07$ & $07 \cdot 00$ & $20: 0.17 .07$ & ב. & hik \\
\hline 1 & $2020-11-00$ & 07:00 & $2020-11-C 0$ & $16: 00$ & Imenาersitkan dapur \\
\hline
\end{tabular}

Figure 11. Report Page of Clean Water Maintenance Work Results

Based on the results of the design of information systems for water maintenance activities at PT. Rezeki Surya Intimakmur, as for the users who are given access rights to use the information system for this 
maintenance activity, namely administration and leadership. The administration has the duties and responsibilities to manage (add, change, delete, save, and print reports) of each data needed to display information on all clean water maintenance activities carried out. The leadership has access rights to be able to monitor and display information and reports from all the data directly and can print the required reports without having to wait from the admin so that based on these reports, strategic decisions can be made regarding the maintenance of clean water at the user company.

\subsection{Implementation and Unit Testing}

This stage is applying the design results in the Visual Basic programming language. At this stage, a trial of the application is carried out to identify the debug of the clean water maintenance activity information system before being tested for functions in the next stage.

\subsection{Integration and System Testing}

In this stage, the integration and implementation of information systems is carried out to see if the information system designed is following user needs. The system integration is carried out by accessing the clean water maintenance activity management application that has been built and then socializing the instructions for using the information system and simulation to the admin to review whether the system is suitable for use and meets the needs defined at an early stage. After three tests and adjustments were made, the information system was used at PT. Sustenance Surya Intimakmur by remaining under the guidance of the research team.

\subsection{Operation and Maintenance}

After the information system meets the required criteria, the distribution is carried out to the users, namely the admin and the leadership of PT. Rezeki Surya Intimakmur to be applied and evaluated to see if the new system has met the objectives to be achieved. The maintenance process is carried out if the information system experiences problems in its operations.

\section{Conclusion}

Based on the results of research and development of application programs up to the implementation stage, the authors draw conclusions, namely: (1) The information system for water maintenance activities is designed using Visual Basic.Net programming and MySQL database can provide convenience for admins in processing clean water maintenance activity reports; and (2) By using a new system using a database, it can minimize the occurrence of data duplication and can make it easier to search for data on maintenance activities that will be, are being, or have been carried out.

\section{References}

[1] E. Yubarda and C. D. Puspita, "Sistem informasi pelayanan jasa servis komputer pada cv. tecnology computer," J. Jar. Sist. Inf. Robot., vol. 5, no. 1, pp. 28-33, 2021.

[2] S. Annisa, "Desain Sistem Penjadwalan Mata Kuliah Menggunakan Bahasa Pemrograman Php/MySQL (Studi Kasus : STAIN Bukittinggi)," Jar. Sist. Inf. Robot., vol. 3, no. 1, pp. 161-168, 2019.

[3] A. A. B. S. Pramono and A. W. Utami, "Rancang Bangun Sistem Informasi Praktik Industri di Jurusan Teknik Informatika Unesa Berbasis Website," Jar. Man. Info., vol. 8, pp. 70-78, 2018.

[4] S. Annisa, "Aplikasi jasa penitipan anak menggunakan bahasa pemrograman visual basic," Jar. Sist. Inf. Robot., vol. 2, no. 2, pp. 67-74, 2020.

[5] H. Ardiyanto and S. Fajaruddin, "Tinjauan atas artikel penelitian dan pengembangan pendidikan di Jurnal Keolahragaan," J. Keolahragaan, vol. 7, no. 1, pp. 83-93, 2019, doi: 10.21831/jk.v7i1.26394.

[6] I. Efendi and S. Annisa, “Penerapan Media Pembelajaran Game Berbasis Android untuk Pengenalan Abjad," Jar. Sist. Inf. Robot., vol. 2, no. 02, pp. 137-145, 2018.

[7] S. Annisa, "Pengembangan Lembar Kerja Siswa Berbasis Model Pembelajaran Kooperatif Pada Mata Pelajaran Keterampilan Komputer Dan Pengelolaan Informasi (Kkpi)," Jar. Sist. Inf. Robot., vol. 1, no. 01, pp. 8-17, 2017.

[8] A. D. Pangesti, "Research and Development: Penelitian yang Produktif Dalam Dunia Pendidikan," Researchgate, vol. 
5, no. 1, pp. 1-8, 2019, doi: 10.13140/RG.2.2.28521.44640.

[9] E. Yubarda and N. Ananda, "Sistem Informasi Rawat Jalan Pada Rumah Sakit Thursina Berbasis Web," J. Jar. Sist. Inf. Robot., vol. 4, no. 2, pp. 61-66, 2020.

[10] E. Yubarda and R. Rahayu, “Sistem Informasi Penjualan Produk Electrical,” J. Sist. Inf. Robot., vol. 3, no. 1, pp. 169176, 2019.

[11] S. Annisa and F. Derisfy, “Sistem Informasi Pengolahan Data Hasil Unloading Oily Sand dari Central Gate Station,” Jar. Sist. Inf. Robot., vol. 3, no. 2, pp. 257-263, 2019. 